\title{
Variations of the Physicochemical Parameters and Metal Levels and Their Risk Assessment in Urbanized Bagmati River, Kathmandu, Nepal
}

\author{
Rukumesh Paudyal, ${ }^{1,2,3,4}$ Shichang Kang, ${ }^{1,5}$ Chhatra Mani Sharma,,4,6 \\ Lekhendra Tripathee, ${ }^{1,2,4}$ and Mika Sillanpää ${ }^{4}$ \\ ${ }^{1}$ State Key Laboratory of Cryospheric Sciences, Northwest Institute of Eco-Environment and Resources, \\ Chinese Academy of Sciences, Lanzhou 730000, China \\ ${ }^{2}$ Himalayan Environment Research Institute (HERI), Kathmandu, Nepal \\ ${ }^{3}$ University of Chinese Academy of Sciences, Beijing 100049, China \\ ${ }^{4}$ Laboratory of Green Chemistry, Lappeenranta University of Technology, Sammonkatu 12, 50130 Mikkeli, Finland \\ ${ }^{5}$ CAS Center for Excellence in Tibetan Plateau Earth Sciences, Chinese Academy of Sciences, Beijing 100085, China \\ ${ }^{6}$ Department of Environmental Science and Engineering, School of Science, Kathmandu University, Dhulikhel, Nepal
}

Correspondence should be addressed to Shichang Kang; shichang.kang@lzb.ac.cn

Received 14 July 2016; Revised 14 September 2016; Accepted 13 October 2016

Academic Editor: Franco Tassi

Copyright (C) 2016 Rukumesh Paudyal et al. This is an open access article distributed under the Creative Commons Attribution License, which permits unrestricted use, distribution, and reproduction in any medium, provided the original work is properly cited.

\begin{abstract}
During post-monsoon 2013, surface water samples were collected form 34 sites from the Bagmati River and its tributaries within the Kathmandu Valley to assess the river water quality. The physical parameters were measured on site and major ions $\left(\mathrm{Na}^{+}, \mathrm{NH}_{4}^{+}\right.$, $\mathrm{K}^{+}, \mathrm{Mg}^{2+}, \mathrm{Ca}^{2+}, \mathrm{Cl}^{-}, \mathrm{SO}_{4}{ }^{2-}$, and $\mathrm{NO}_{3}{ }^{-}$) and 17 elements in water were analyzed in the laboratory. Conductivity ranged from 21.92 to $846 \mu \mathrm{S} / \mathrm{cm}$, while turbidity ranged from 2.52 to $223 \mathrm{NTU}$ and dissolved oxygen (DO) ranged from 0.04 to $8.98 \mathrm{mg} / \mathrm{L}$. The ionic and elemental concentrations were higher in the lower section where the population density is high compared to the headwaters. The large input of wastewater and organic load created anoxic condition by consuming dissolved oxygen along the lower belt of the river. The concentration of the elements was found to be in the order of $\mathrm{Mn}>\mathrm{Zn}>\mathrm{Ti}>\mathrm{Rb}>\mathrm{Cr}>\mathrm{Cu}>\mathrm{Sc}>\mathrm{Ni}>\mathrm{V}>\mathrm{Li}>$ $\mathrm{Co}>\mathrm{Mo}>\mathrm{Cd}>\mathrm{Y}>\mathrm{Ga}>\mathrm{Be}>\mathrm{Nb}$. The concentration of $\mathrm{Mn}, \mathrm{Cd}, \mathrm{Cr}, \mathrm{Co}$, and $\mathrm{Zn}$ was particularly higher in urban and semiurban sections. Enrichment factor (EF) calculations for Cd, Co, and Zn showed their highly enriched values indicating that these elements originated from anthropogenic sources. Preliminary risk assessments were determined by the hazard quotient (HQ) calculations in order to evaluate the health risk of the metals. The $\mathrm{HQ}_{\text {ingestion }}$ values of elements were found to be in the order $\mathrm{Sb}>\mathrm{Mn}>\mathrm{Cr}>$ $\mathrm{V}>\mathrm{Co}>\mathrm{Cd}>\mathrm{Cu}>\mathrm{Zn}>\mathrm{Ni}>\mathrm{Li}>\mathrm{Mo}$ with all averaged HQ values less than 1, indicating no or limited health risk of metals from the river to the local residence. However the values of $\mathrm{Sb}$ in some parts of the Bagmati were close to unity indicating its possible threat. Anthropogenic activities like industrial activities, municipal waste water, and road construction besides the river appear to control the chemical constituent of the river water. Overall the river was highly polluted with elevated concentrations of major ions and elements and there is a need for restoration projects.
\end{abstract}

\section{Introduction}

Metal contamination in fresh water has been global problem because of its toxicity, abundance, and persistence [1-3]. The rate of heavy metals release to the rivers worldwide is increasing rapidly mainly due to the rapid growth of urban population and increased industrial and agricultural production [4-7]. Furthermore, their distribution and accumulation in the environment have been increasing at an alarming rate affecting human and other aquatic organisms $[8,9]$. Many anthropogenic activities like disposal of industrial and domestic wastes, agriculture, construction of roads 
and buildings, and deforestation are known to affect water chemistry [10-13]. Similarly, increase in ions concentration could be a result of increased population, for example, in the United States [14], France, and Germany [15-17].

Water resources from the Bagmati River System are important for small scale hydroelectricity and irrigation and as drinking water sources. About $82 \%$ of water volume is extracted daily from the surface water sources for drinking water supply in the Kathmandu Valley. On the other hand, these rivers are extensively being used as dumping sites for solid wastes, outlets for domestic sewerage, and industrial and agricultural effluents. Also, the river banks are being encroached upon by slum dwellers without any restrictions from the government. Furthermore, due to heavy traffic in the city, the demands of new road channel are increasing; hence construction of roads by the banks of river without proper study is common these days. All these negative approaches in addition to uncontrolled and mismanaged growth of urban population are affecting the balance of the riverine ecology in the valley. In addition, the uncontrolled quarrying of sand has tremendously affected the selftreatment capacity of the rivers.

In this paper we focus on the contribution of chemical load from the tributaries of Bagmati into its main stream. In the past, there have been few studies about the water chemistry of main stream of Bagmati River which have focused mainly on nutrients, major ions, and trace elements with limited sampling points [18-23]. However, there is a lack of information on the chemistry of the tributaries of Bagmati River, their possible sources within the valley, and trace metals induced human risk assessments. This study, for the first time, provides the detailed information from the tributaries of Bagmati, water quality health assessment in the Bagmati River during the current state of rapid urbanization, and socioeconomic development including the risk assessment from trace metals.

\section{Materials and Methods}

\subsection{Study Area}

2.1.1. Geological Settings. This study was conducted in the Bagmati River and its tributaries in the Kathmandu Valley, Central Nepal (Figure 1). Kathmandu lies in the middle mountain region of Nepal. It is roughly circular bowl-shaped valley with diameter of about 25 to $30 \mathrm{~km}$ [24]. It covers an area of approximately $650 \mathrm{~km}^{2}$ with an average altitude of $1340 \mathrm{~m}$ [25]. The Bagmati is not a snow-fed river and most of its water is contributed by runoff. The origin of Bagmati is at Shivapuri and surrounding mountain range. There are 24 main tributaries originating from Mahabharat and Siwalik range which feed the Bagmati River [26]. The Bagmati River system drains about $3,500 \mathrm{~km}^{2}$ before crossing the boundary of India and eventually draining into the Ganges [23]. The Bagmati river system consists of three major rivers flowing through the Kathmandu Valley, namely, Bagmati, Bishnumati, and Manahara. Kathmandu Valley was a lake during Plio/Pleistocene times and silted up by lacustrine and deltaic river sediments [27]. The basin filled sediments are mainly loam and composed of unconsolidated clay, silt, sand, and gravels. The headwaters of Bagmati river contain mica gneiss and biotite schist with muscovite, whereas the southern part of the river consists of thick clay formation and basal gravel [28] and the bed rock downstream contains fine grained phyllite, quartz containing argillaceous limestone, slates, shales, claystones, and mudstones $[29,30]$. In this study we consider samples from 5 major tributaries (Manahara, Dhobi, Tukucha, Bishnumati, and Balkhu Khola) and some minor tributaries (Mahadev Khola, Hanumante, and Godavari). The study stretch in the main stream of Bagmati River is about $37 \mathrm{~km}$ in length from Sundarijal to Khokana.

2.1.2. Land-Use. There have been rapid urbanization in Kathmandu Valley as it is the capital city and center of attraction to the Nepalese population. In 1976, the total urban/built-up area in Kathmandu was about $17 \%$, but in 2009 the percentage increased to almost $67 \%$. In the same period the Forest Cover area was reduced from $14 \%$ to $2.3 \%$ [31]. This can have an immense effect on the river water quality.

The climate of Kathmandu Valley is subtropical cool temperate with maximum temperature of $35.6^{\circ} \mathrm{C}$ in April and minimum of -2.5 in January and $75 \%$ annual average humidity. The temperature on average is $19^{\circ} \mathrm{C}$ to $27^{\circ} \mathrm{C}$ in summer and $2^{\circ} \mathrm{C}$ to $20^{\circ} \mathrm{C}$ in winter; the average rainfall is 1400 millimeters, most of which falls during monsoon. Monsoon is generally observed during June-September.

Kathmandu Valley comprises three districts, Kathmandu, Lalitpur, and Bhaktapur. The valley encloses the entire area of Bhaktapur, $85 \%$ of Kathmandu, and $50 \%$ of Lalitpur District. The total population of Kathmandu Valley is more than 2.5 million according to the population census of 2011.

2.2. Sampling and Laboratory Analysis. Water samples were collected from the Bagmati River and its tributaries during October 2013 (after monsoon). The analyses were performed for trace elements and major ions. Alltogether, 34 samples were collected from different tributaries of Bagmati river basin. In situ measurements were carried out for air temperature, water temperature, $\mathrm{pH}$, conductivity, turbidity, DO, and TDS. A WagTech pH meter (WAG-WE30200), WagTech conductivity meter (WAG-WE30210), and turbidity meter (WAG-WE30210) were used in the field for in situ measurements. Water samples were collected into $20 \mathrm{~mL}$ ultraclean HDPE (High Density Polyethylene) bottles after filtering through $0.45 \mu \mathrm{m}$ polypropylene membrane filters. The sampling bottles were rinsed with river waters thrice before the original samples were taken. All samples were taken at a depth of approximately $30 \mathrm{~cm}$ below water surface. The sampled bottles were packed inside the double polyethylene zip-lock bags and kept in refrigerator at $4^{\circ} \mathrm{C}$ until the laboratory analysis [32].

All samples for trace elements were acidified to $\mathrm{pH}<$ 2 with ultrapure $\mathrm{HNO}_{3}$ before analyses in order to dissolve the trace elements and to prevent their adsorption on the walls of the bottles. The samples were organized for the different laboratory analysis. Samples were analyzed for 17 


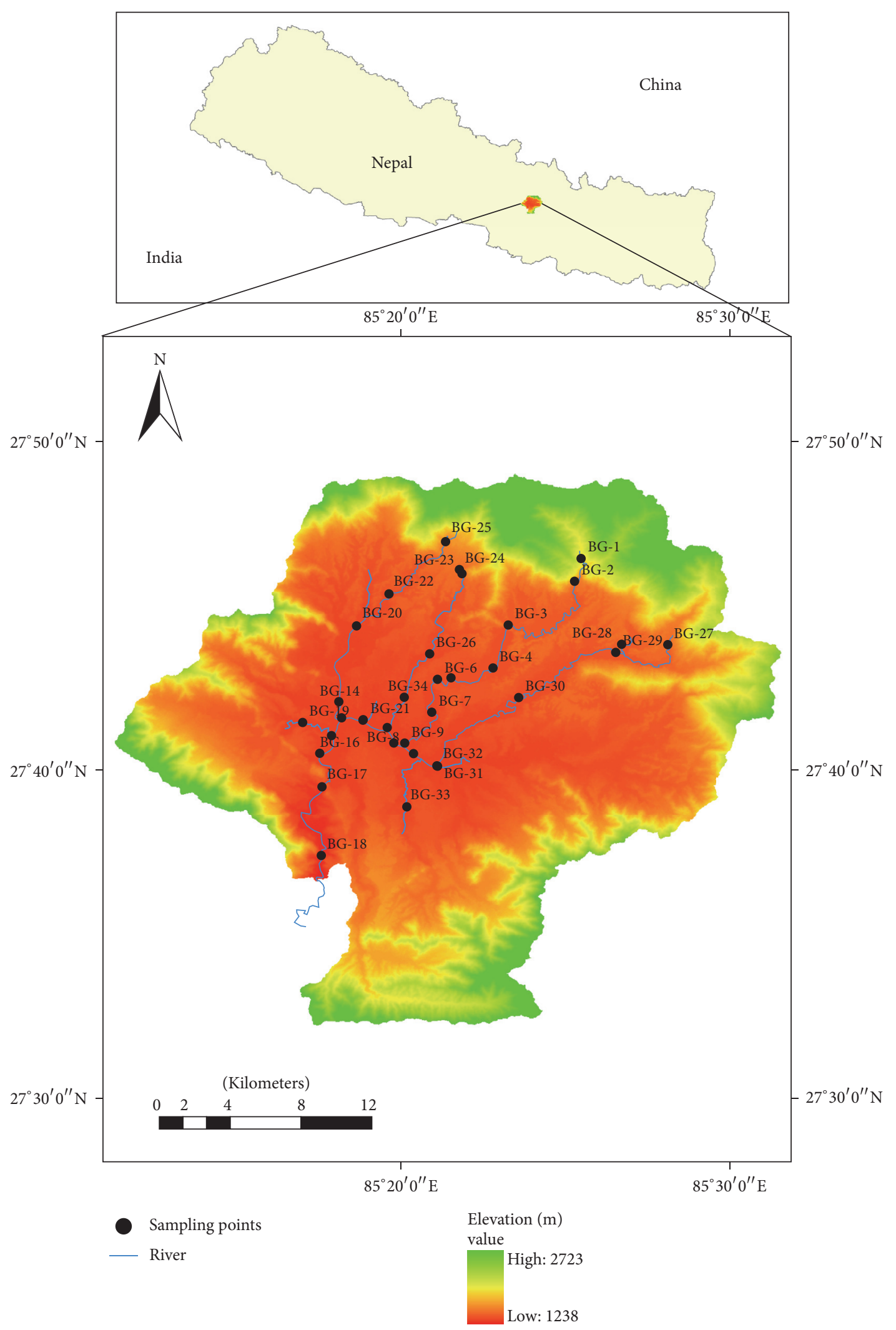

FIGURE 1: The map of the study area showing the sampling points in Bagmati and its tributaries within the Kathmandu Valley. 
elements (Li, Be, Sc, Ti, V, Mn, Cr, Co, Ni, Cu, Zn, Ga, Rb, $\mathrm{Y}, \mathrm{Nb}, \mathrm{Mo}$, and $\mathrm{Cd}$ ) directly by inductively coupled plasmamass spectrometry (ICP-MS, X-7 Thermo Elemental) at the Institute of Tibetan Plateau Research (ITP-CAS). The samples for major ions $\left(\mathrm{Na}^{+}, \mathrm{NH}_{4}, \mathrm{~K}^{+}, \mathrm{Mg}^{2+}, \mathrm{Ca}^{2+}, \mathrm{Cl}^{-}, \mathrm{SO}_{4}{ }^{2-}\right.$, and $\mathrm{NO}_{3}{ }^{-}$) were analyzed at the State Key Laboratory of Cryospheric Sciences, Cold and Arid Regions Environmental and Engineering Research Institute, Chinese Academy of Sciences (CAREERI-CAS). Major cations were analyzed by Dionex ISC 2000 ion chromatograph using an IonPac CS12A column, $20 \mathrm{mM}$ methanesulfonic acid eluent, and CSRS300 suppresser. Major anions were analyzed by Dionex ISC 2500 ion chromatograph using an IonPac AS11-HC column, $25 \mathrm{mM} \mathrm{NaOH}$ eluent, and ASRS300 suppresser. The detection limits were less than $1 \mu \mathrm{g} / \mathrm{L}[33]$.

2.3. Quality Control, Ionic Balance, and Data Analysis. Special care was taken during the field sample collection and laboratory analysis. Nonpowder vinyl clean room gloves and masks were worn to avoid the possible contaminations in the field as well as in the Laboratory. All the samples were kept frozen in the laboratory until analysis. Three field blanks were prepared with deionized water and taken in the field and were analyzed for trace elements and major ions. The field blank samples showed very negligible contamination during sampling, storage, and transportation of the samples. The ionic balance between anions $\left(\mathrm{F}^{-}, \mathrm{Cl}^{-}, \mathrm{NO}_{2}{ }^{2-}, \mathrm{SO}_{4}{ }^{2-}\right.$, and $\left.\mathrm{NO}_{3}{ }^{-}\right)$and cations $\left(\mathrm{Na}^{+}, \mathrm{NH}_{4}{ }^{+}, \mathrm{K}^{+}, \mathrm{Mg}^{2+}\right.$, and $\left.\mathrm{Ca}^{2+}\right)$ were evaluated by regression analysis, $\sum$ anions $=0.26 \times$ $\sum$ cations $-80.74\left(R^{2}=0.78\right)$, suggesting an acceptable data quality. Details of sampling, analysis, and quality control have been explained elsewhere [32-35]. Some statistical analysis like Pearson's correlation and Principle Component Analysis (PCA) were performed using IBM SPSS19 statistics.

2.4. Enrichment Factor. Enrichment factor (EF) is considered as an effective tool to evaluate the magnitude of contaminants in the environment from anthropogenic influence [36-38]. EF calculations for the trace elements have been previously found to be efficient for the study of precipitation [35] and surface water [39] in Nepal. EF can be calculated using the following equation:

$$
\mathrm{EF}_{x}=\frac{\left(C_{x} / C_{r}\right) \text { riverwater }}{\left(C_{x} / C_{r}\right) \text { soil }}
$$

where $x$ represents the element of interest; $\mathrm{EF}_{x}$ is the enrichment factor of $x ; C_{x}$ is the concentration of $x$; and $C_{r}$ is the concentration of a reference element. Generally, Al, $\mathrm{Li}, \mathrm{Fe}, \mathrm{Sc}$, and $\mathrm{Zr}$ are considered as reference elements. $\mathrm{Li}$ was selected as the reference element for calculating EF, as it is not subject to anthropogenic enrichment. For this study top soil composition of Tibet was considered [40] because of its proximity to the study area instead of upper continental crust (UCC) [41]. Tripathee et al. [35] also considered soil composition of Tibet to calculate EF and found that it was effective for the regions. However, recent study by Tripathee et al. [42] has suggested that both UCC and Tibetan top soil could be used for EF calculations in the southern Himalayas, Nepal. Elements with EF close to 1 are considered as having strong natural influence. Samples having EF $>1.5$ are considered indicative of human influence [43], an EF value higher than 4 indicates some anthropogenic sources [37] and elements having EF greater than 10 are regarded to be severely affected by anthropogenic origin.

2.5. Risk Assessment. Some of the important pathways of trace metals entering into human body include ingestion, dermal adsorption, and inhalation in surface water environment [44-46]. Using ingestion and dermal pathways, hazard quotients (HQs) associated with corresponding metals were assessed via a risk assessment model. The exposure dose is calculated as modified from the US Environmental Protection Agency [47] using

$$
\begin{aligned}
D_{\text {ingestion }} & =\frac{C_{w} \times \mathrm{IRW} \times \mathrm{EF} \times \mathrm{ED}}{\mathrm{BW} \times \mathrm{AT}}, \\
D_{\text {dermal }} & =\frac{C_{w} \times \mathrm{SA} \times K_{p} \times \mathrm{ET} \times \mathrm{EF} \times \mathrm{ED} \times \mathrm{CF}}{\mathrm{BW} \times \mathrm{AT}},
\end{aligned}
$$

where $C_{w}$ is average concentration of trace metals in water. IRW is drinking water ingestion rate ( $2 \mathrm{~L} /$ day). $\mathrm{EF}$ is exposure frequency (350 days/year). ED is exposure duration (30 years). BW is body weight $(70 \mathrm{~kg})$. AT is average time for noncarcinogens and carcinogens (10950). SA is exposed skin area $\left(2800 \mathrm{~cm}^{2}\right) . K_{p}$ is dermal permeability constant, $\mathrm{cm} / \mathrm{hr}$, $\mathrm{C}$ is $0.0004, \mathrm{Ni}$ is $0.0002, \mathrm{Zn}$ is 0.0006 , and $\mathrm{Cr}$ is 0.002 for other metals: 0.001 . ET is exposure time $0.6 \mathrm{~h} /$ day. $\mathrm{CF}$ is unit conversion factor; for water, it is equal to $1 \mathrm{~L} / 1000 \mathrm{~cm}^{3}$.

However the hazard quotient (HQ) is calculated as follows:

$$
\mathrm{HQs}=\frac{D}{\mathrm{RfD}} \text {. }
$$

$\mathrm{RfD}$ is the reference dose for different analytes expressed in $\mu \mathrm{g} / \mathrm{kg} /$ day, which is based on US risk based assessment [48]

\section{Results and Discussion}

3.1. Physical Parameters and Major Ions Concentration. The average concentration of ions and physical parameters in the headwaters and semiurban and urban stretch of the river for all the samples are presented in Table 1. The concentration of every parameter except $\mathrm{pH}$ and dissolved oxygen showed much higher concentration in urban and semiurban areas compared to the headwaters of Bagmati river basin. $\mathrm{pH}$ ranged from 6.07 at Balkhu (BG-15) to 8.05 in headwater of Dhobi Khola at Chapali (CG-23). BG-15 sample was collected near the vegetable market of Balkhu, which is one of the most polluted sections of Bagmati river basin. However the range of $\mathrm{pH}$ value along the Bagmati river system is within a typical river water value (4.5-8.5), as suggested by McCutcheon et al. [49]. Lowest conductivity, total dissolved solids, and highest dissolved oxygen were found in Sundarijal Bazzar (BG-2), one of the main headwaters of Bagmati River with high flow rate. On the contrary, high conductivity, high TDS, and low 
TABLE 1: Variation of measured major ions ( $\mu \mathrm{eq} / \mathrm{L})$, conductivity $(\mu \mathrm{S} / \mathrm{cm})$, turbidity (NTU), DO (mg/L), and TDS (mg/L) in three different sections of the Bagmati River basin within Kathmandu Valley. Values in brackets indicate standard deviation.

\begin{tabular}{lcccccc}
\hline \multirow{2}{*}{ Parameters } & \multicolumn{2}{c}{ Headwater } & \multicolumn{2}{c}{ Semiurban } & \multicolumn{2}{c}{ Urban } \\
& Range & Average (SD) & Range & Average (SD) & Range & Average (SD) \\
\hline $\mathrm{F}^{-}$ & $6.67-12.64$ & $9.71(2.22)$ & $8.05-50.02$ & $17.00(12.31)$ & $12.40-1122.89$ & $152.72(300)$ \\
$\mathrm{Cl}^{-}$ & $3.04-44.20$ & $22.15(13.6)$ & $15.19-320.41$ & $138.41(118.96)$ & $117.59-1035.45$ & $392.41(249.4)$ \\
$\mathrm{SO}_{4}{ }^{2-}$ & $1.58-23.40$ & $11.01(7.44)$ & $7.4-72.17$ & $33.48(20.71)$ & $13.79-189.50$ & $70.49(39.34)$ \\
$\mathrm{NO}_{3}{ }^{-}$ & $12.16-69.13$ & $43.60(24.08)$ & $0-488.51$ & $94.93(144.55)$ & $0-382.62$ & $86.36(123.9)$ \\
$\mathrm{Na}^{+}$ & $101.14-259.99$ & $202.19(61.56)$ & $73.35-1115.69$ & $472.49(366.28)$ & $467.19-2573.30$ & $1124.38(647.1952)$ \\
$\mathrm{NH}_{4}{ }^{-}$ & $23.13-131.29$ & $79.32(39.50)$ & $47.02-557.40$ & $221.74(178.79)$ & $177.10-1146.64$ & $595.05(300.89)$ \\
$\mathrm{K}^{+}$ & $8.47-34.07$ & $25.10(10.07)$ & $11.09-196.91$ & $85.29(70.92)$ & $59.78-493.18$ & $218.31(139.76)$ \\
$\mathrm{Mg}^{2+}$ & $4.57-48.56$ & $30.40(17.36)$ & $14.41-409.76$ & $151.80(137.51)$ & $76.21-361.23$ & $203.27(88.67)$ \\
$\mathrm{Ca}^{2+}$ & $30.94-301.60$ & $172.84(95.24)$ & $88.71-1752.57$ & $668.38(569.01)$ & $261.04-1116.36$ & $779.18(262.47)$ \\
$\mathrm{pH}$ & $7.07-8.05$ & $7.49(0.31)$ & $6.52-7.7$ & $7.16(0.377)$ & $6.07-7.62$ & $7.06(0.41)$ \\
$\mathrm{Conductivity}$ & $21.92-255$ & $83.36(65.97)$ & $63.10-538$ & $259.93(183.3)$ & $174-846$ & $491.38(205.67)$ \\
Turbidity & $2.52-18.67$ & $6.95(5.37)$ & $14.39-223$ & $50.65(63.11)$ & $13.32-222$ & $57.96(52.51)$ \\
Dissolved oxygen & $5.21-8.98$ & $6.76(1.07)$ & $0.37-6.29$ & $3.63(2.26)$ & $0.04-4.7$ & $1.80(1.53)$ \\
TDS & $11.8-129$ & $42.06(33.36)$ & $31.5-265$ & $130.10(91.06)$ & $87.5-418$ & $248.16(98.26)$ \\
\hline
\end{tabular}

TABLE 2: Pearson correlation matrix among some major ions in the water samples from Bagmati drainage system within Kathmandu Valley.

\begin{tabular}{|c|c|c|c|c|c|c|c|c|c|}
\hline & $\mathrm{F}^{-}$ & $\mathrm{Cl}^{-}$ & $\mathrm{SO}_{4}{ }^{2-}$ & $\mathrm{NO}_{3}{ }^{-}$ & $\mathrm{Na}^{+}$ & $\mathrm{NH}_{4}{ }^{-}$ & $\mathrm{K}^{+}$ & $\mathrm{Mg}^{2+}$ & $\mathrm{Ca}^{2+}$ \\
\hline $\mathrm{F}^{-}$ & 1 & & & & & & & & \\
\hline $\mathrm{Cl}^{-}$ & $.74^{* *}$ & 1 & & & & & & & \\
\hline $\mathrm{SO}_{4}{ }^{2-}$ & .01 & $.63^{* *}$ & 1 & & & & & & \\
\hline $\mathrm{NO}_{3}^{-}$ & -.12 & -.10 & -.07 & 1 & & & & & \\
\hline $\mathrm{Na}^{+}$ & $.72^{* *}$ & $.97^{* *}$ & $.58^{* *}$ & -.07 & 1 & & & & \\
\hline $\mathrm{NH}_{4}^{-}$ & $.62^{* *}$ & $.92^{* *}$ & $.65^{* *}$ & -.25 & $.94^{* *}$ & 1 & & & \\
\hline $\mathrm{K}^{+}$ & $.71^{* *}$ & $.95^{* *}$ & $.57^{* *}$ & -.11 & $.99^{* *}$ & $.96^{* *}$ & 1 & & \\
\hline $\mathrm{Mg}^{2+}$ & $.46^{* *}$ & $.79^{* *}$ & $.59^{* *}$ & .22 & $.83^{* *}$ & $.74^{* *}$ & $.83^{* *}$ & 1 & \\
\hline $\mathrm{Ca}^{2+}$ & .33 & $.67^{* *}$ & $.53^{* *}$ & $.36^{*}$ & $.71^{* *}$ & $.61^{* *}$ & $.70^{* *}$ & $.96^{* *}$ & 1 \\
\hline
\end{tabular}

${ }^{* *}$ Correlation is significant at the 0.01 level (2-tailed).

${ }^{*}$ Correlation is significant at the 0.05 level (2-tailed).

dissolved oxygen were found in the urban section of Dhobi Khola at Buddha Nagar (BG-11) and Maitidevi (BG-34). Conductivity of the river was found to increase from headwaters to the area downstream due to the increased intensity of anthropogenic activities downstream. Furthermore, turbidity ranged from 2.52 at Sundarijal above Dam (BG-1) to 223 at Bagmati Nagar (BG-5). Bagmati Nagar is a suburban section of the Bagmati river basin. The high turbidity must be due to high sediment loading in the downstream.

All the measured major ions showed an increasing trend from headwaters to semiurban to urban section except for nitrate ions. Nitrate ions decreased from semi urban to urban mainly due to the high population density in the urban section of the river. The major ions compositions in equivalent per litre in headwaters were $\mathrm{Na}^{+}>\mathrm{Ca}^{++}>$ $\mathrm{NH}_{4}{ }^{+}>\mathrm{NO}_{3}{ }^{-}>\mathrm{Mg}^{2+}>\mathrm{K}^{+}>\mathrm{Cl}^{-}>\mathrm{SO}_{4}{ }^{2-}>\mathrm{F}^{-}$, suburban was $\mathrm{Ca}^{2+}>\mathrm{Na}^{+}>\mathrm{NH}_{4}^{+}>\mathrm{Mg}^{2+}>\mathrm{Cl}^{-}>$ $\mathrm{NO}_{3}{ }^{-}>\mathrm{K}^{+}>\mathrm{SO}_{4}{ }^{2-}>\mathrm{F}^{-}$, and urban stretch of the river was $\mathrm{Na}^{+}>\mathrm{Ca}^{2+}>\mathrm{NH}_{4}^{+}>\mathrm{Cl}^{-}>\mathrm{K}^{+}>\mathrm{Mg}^{2+}>$ $\mathrm{F}^{-}>\mathrm{NO}_{3}{ }^{-}>\mathrm{SO}_{4}{ }^{2-}$, respectively. The concentration of $\mathrm{NO}_{3}{ }^{-}, \mathrm{Ca}^{2+}, \mathrm{Na}^{+}, \mathrm{SO}_{4}{ }^{2-}, \mathrm{Mg}^{2+}, \mathrm{NH}_{4}{ }^{+}, \mathrm{K}^{+}, \mathrm{F}^{-}$, and $\mathrm{Cl}^{-}$ was $2,4,5,6,6,7,8,15$, and 17 times higher, respectively, in urban stretch compared to the headwaters. Correlations among ions are presented in Table 2. Chlorine ion is highly correlated with many ions like $\mathrm{F}^{-}, \mathrm{Na}^{+}, \mathrm{NH}_{4}{ }^{+}, \mathrm{K}^{+}$, and $\mathrm{Mg}^{2+}$, suggesting their common source of origin. High amount of $\mathrm{Cl}^{-}$ions is mainly from anthropogenic sources [16, 20, 50], which might have originated from domestic effluents, roads, and industries in the river system. Moreover, the high value of $\mathrm{Cl}^{-}$concentration is an indicator of unforested land and is considered as good indicator of human disturbance [51]. The possible sources of $\mathrm{K}^{+}$are domestic wastes and fertilizers. On the other hand, low sulfate concentrations in comparison to chloride might be due to sulfate reduction to sulfide occurring as a result of high organic load. Nitrate concentrations were very low in the samples with low DO concentrations suggesting lack of oxygen limits nitrification which enhances denitrification $[17,52,53]$. Figure 2 shows the variation of conductivity, DO, and TDS along the distance in the main stream of Bagmati River. Generally, DO showed a decreasing trend with distance (Figure 2(b)); however in some of the lower reaches of Bagmati River, DO was relatively 


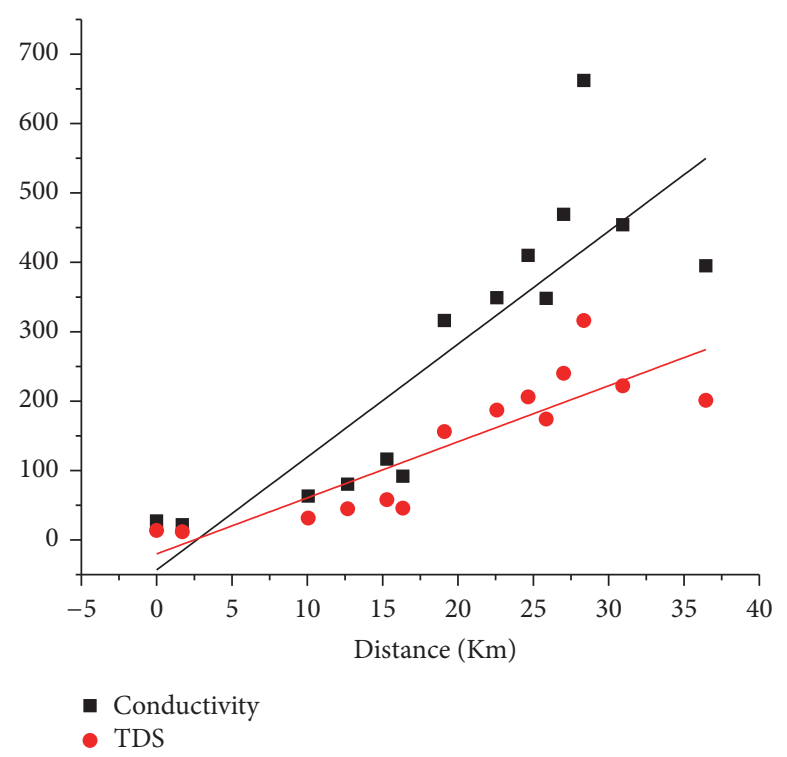

(a)

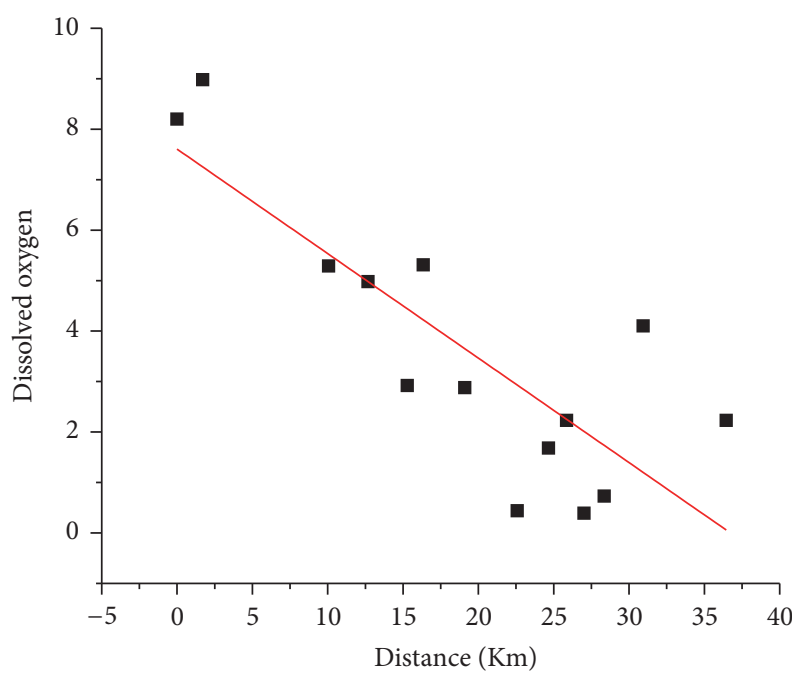

- Conductivity

(b)

FIGURE 2: Variation of (a) conductivity ( $\mu \mathrm{S} / \mathrm{cm})$, TDS (mg/L), and (b) dissolved oxygen $(\mathrm{mg} / \mathrm{L})$ along the Bagmati River within the Kathmandu Valley (the distance was measured from the headwater).

high due to good mixing. In such samples, the concentration of nitrate was high suggesting nitrification in the presence of oxygen. In addition, variation of conductivity and TDS was also plotted with distance (Figure 2(a)), which showed an increasing trend with distance suggesting high input of ions in the downstream river with high population density. Ammonium had a good correlation with chloride, potassium, and sodium, suggesting their common sources in the river systems. High concentration of $\mathrm{NH}_{4}{ }^{+}$appears to be released by anthropogenic sources such as untreated domestic sewage and agricultural and industrial effluent. The concentration of $\mathrm{NH}_{4}{ }^{+}$was extremely high in semiurban and urban region of the Bagmati basin. The use of chemical pesticides and fertilizers has been common in the agriculture lands of the Kathmandu Valley, which has high contribution in the Bagmati nutrient load [54]. Similarly, carpet, garment, and other small scale industries also play a significant role in the contribution of chemical loads.

3.2. Elemental Composition. Average concentrations of elements in headwaters and semiurban and urban sites are shown in Table 3. The concentration of $\mathrm{Mg}$ and $\mathrm{Zn}$ appeared to be higher than other elements. All the elements showed a high concentration in urban areas and semiurban areas. The increase in concentration of elements like $\mathrm{Mn}, \mathrm{Cd}, \mathrm{Cr}$, $\mathrm{Co}$, and $\mathrm{Zn}$ was particularly high from headwaters to the urban sites. The concentration of $\mathrm{Cd}$ was not detected in the headwater but, however, was observed in the semiurban and urban stretches of the river (Table 3). The concentration of $\mathrm{Cd}$ was higher than observed in the previous study in the Bagmati [23], suggesting increase of such anthropogenic metal levels in the river. The high value of $\mathrm{Cd}$ might be attributed to industrial activities downstream. On the other hand, the concentration of $\mathrm{Zn}$ is lower in headwater and suburban water compared to the data reported by Bhatt et al. [23] suggesting the natural restoration in the upper zone. However, in the urban section the concentration of $\mathrm{Zn}$ was high in our study. Such a result is an indication that other tributaries must be contributing to more $\mathrm{Zn}$ downstream. The sources of $\mathrm{Zn}$ are domestic construction, car related waste, and untreated waste water [55]. The concentration of $\mathrm{Cr}$ was $3 \mu \mathrm{g} / \mathrm{L}, 8 \mu \mathrm{g} / \mathrm{L}$, and $17 \mu \mathrm{g} / \mathrm{L}$, respectively, in headwaters and semiurban and urban section of the river. These values are higher than in Buriganga [9] and lower compared to the Korotoa River [3] in Bangladesh and Orge River in France [56]; both are urban rivers. However, the values were still higher than the WHO guidelines of $5 \mu \mathrm{g} / \mathrm{L}$ [57] in semiurban and urban sections. Similarly, the concentration of $\mathrm{Ni}, \mathrm{Cu}$, and Cd was 14-, 5-, and 21-fold lower than those found in River Korotoa in Bangladesh [3]. The concentration of cobalt was $0.0092 \mu \mathrm{g} / \mathrm{L}, 0.2 \mu \mathrm{g} / \mathrm{L}$, and $0.38 \mu \mathrm{g} / \mathrm{L}$ in headwaters and semiurban and urban areas, respectively. These values were lower than Orge River in France [56]. Interestingly, these concentrations were comparable to Indrawati $(0.12 \mu \mathrm{g} / \mathrm{L})$ and Dudh Koshi $(0.8 \mu \mathrm{g} / \mathrm{L})$ which are remote rivers of Nepal with limited anthropogenic pressure in the surroundings and the only source of pollutants is long range transport [32]. Similarly, the concentration of $\mathrm{Ni}$ was slightly lower in the Bagmati compared to the Indrawati and Dudh Koshi indicating that there is limited source of cobalt and nickel in the Bagmati River [32]. Furthermore, the concentration of $\mathrm{Mn}, \mathrm{Co}, \mathrm{Ni}, \mathrm{Zn}$, and $\mathrm{Cd}$ was lower in our study compared to Guamaxung-chu near Lhasa [58], which is a stream with high impact of mining activities, indicating that the elements like $\mathrm{Mn}, \mathrm{Co}, \mathrm{Ni}, \mathrm{Zn}$, and $\mathrm{Cd}$ are more influenced by mining than municipal waste. Previous studies $[15,20,22]$ have suggested 
TABLE 3: Variation of average concentration (expressed in $\mu \mathrm{g} / \mathrm{L}$ ) of the elements in three sections of the Bagmati River basin within the Kathmandu Valley.

\begin{tabular}{lcccccccccccccc}
\hline & Detection limit & \multicolumn{4}{c}{ Headwater } & \multicolumn{4}{c}{ Semiurban } & \multicolumn{4}{c}{ Urban } \\
& & Max & Min & Mean & SD & Max & Min & Mean & SD & Max & Min & Mean & SD \\
\hline $\mathrm{Li}$ & 0.024 & 1.98 & 0.47 & 0.98 & 0.50 & 2.35 & 0.28 & 1.18 & 0.62 & 3.00 & 0.60 & 1.66 & 0.72 \\
$\mathrm{Be}$ & 0.004 & 0.05 & 0.01 & 0.02 & 0.01 & 0.06 & 0.00 & 0.03 & 0.02 & 0.06 & 0.00 & 0.03 & 0.02 \\
$\mathrm{Sc}$ & 0.012 & 6.29 & 2.63 & 4.68 & 1.05 & 7.49 & 1.68 & 4.52 & 1.71 & 7.99 & 1.83 & 5.37 & 2.01 \\
$\mathrm{Ti}$ & 0.064 & 8.02 & 1.59 & 5.13 & 2.07 & 29.00 & 2.00 & 11.29 & 7.95 & 39.90 & 7.03 & 21.64 & 10.70 \\
$\mathrm{~V}$ & 0.007 & 1.83 & 0.28 & 1.21 & 0.55 & 3.74 & 0.26 & 1.28 & 1.05 & 2.50 & 0.65 & 1.63 & 0.58 \\
$\mathrm{Mn}$ & 0.005 & 29.60 & 0.52 & 11.05 & 10.54 & 257.00 & 23.00 & 95.97 & 77.66 & 233.00 & 70.50 & 158.71 & 56.58 \\
$\mathrm{Cr}$ & 0.03 & 4.99 & 0.75 & 2.90 & 1.41 & 20.90 & 0.63 & 8.67 & 8.01 & 29.80 & 1.00 & 17.27 & 8.98 \\
$\mathrm{Co}$ & 0.008 & 0.22 & 0.04 & 0.12 & 0.06 & 0.73 & 0.18 & 0.42 & 0.20 & 0.86 & 0.28 & 0.58 & 0.19 \\
$\mathrm{Ni}$ & 0.017 & 0.52 & 0.02 & 0.29 & 0.20 & 2.63 & 0.33 & 1.20 & 0.75 & 4.13 & 0.93 & 2.18 & 1.06 \\
$\mathrm{Cu}$ & 0.079 & 3.60 & 0.18 & 1.25 & 1.25 & 20.80 & 0.58 & 3.96 & 6.38 & 36.60 & 1.27 & 11.29 & 9.10 \\
$\mathrm{Zn}$ & 0.034 & 13.60 & 4.14 & 6.51 & 3.33 & 40.90 & 6.02 & 12.71 & 10.74 & 96.70 & 7.13 & 37.05 & 25.25 \\
$\mathrm{Ga}$ & 0.003 & 0.08 & 0.01 & 0.04 & 0.02 & 0.17 & 0.03 & 0.08 & 0.04 & 0.24 & 0.06 & 0.13 & 0.05 \\
$\mathrm{Rb}$ & 0.005 & 3.09 & 0.51 & 1.85 & 0.89 & 31.60 & 1.65 & 9.58 & 9.52 & 48.70 & 6.20 & 22.98 & 15.55 \\
$\mathrm{Y}$ & 0.0002 & 0.28 & 0.01 & 0.14 & 0.10 & 0.42 & 0.02 & 0.20 & 0.13 & 0.58 & 0.11 & 0.29 & 0.14 \\
$\mathrm{Nb}$ & 0.002 & 0.02 & 0.01 & 0.01 & 0.01 & 0.08 & 0.00 & 0.02 & 0.02 & 0.09 & 0.01 & 0.04 & 0.02 \\
$\mathrm{Mo}$ & 0.002 & 0.16 & 0.04 & 0.09 & 0.04 & 0.68 & 0.06 & 0.26 & 0.22 & 1.17 & 0.19 & 0.49 & 0.29 \\
$\mathrm{Cd}$ & 0.003 & 0.02 & 0.00 & 0.01 & 0.01 & 1.21 & 0.00 & 0.20 & 0.43 & 2.42 & 0.02 & 0.38 & 0.62 \\
\hline
\end{tabular}

that the Bagmati River is one of the most polluted rivers in the world; however, the concentration of some heavy metals is lower than Seine River, Korotoa River, and Orge River mostly because of differences in the industrial inputs. The major anthropogenic sources of the Bagmati are untreated domestic waste, urban development, landfill sites along the bank of the river, and some small scale industrial activities.

The concentration of all the measured elements in the main stream of Bagmati River showed an increasing trend with distance for $25 \mathrm{~km}$ from the first sampling site. However, for the samples downstream, the elemental concentration did not show any specific pattern mainly due to the variability in input of chemical load from other tributaries like Tukucha, Bishnumati, Balkhu, and also inputs from domestic and industrial effluents. Figure 3 shows that the elements concentration was very low at Guheshwori (BG-6). The elemental concentration reaches very low values mainly because of the presence of water treatment plant (WTP) just before the sampling point. This water treatment plant was established because of the presence of holy Hindu temple named Pashupatinath. The concentration of elements starts to increase and the highest peak for all the elements was found near the Kritipur (below the suspension bridge). This may be due to the presence of dumping site in the area. The concentration of elements reduces when it reaches Chovar, the exit of Bagmati River from the Kathmandu Valley suggesting the high gradient as the river passes through a small channel, increasing the flow velocity, hence resulting in low residence time of the elements. In general, the concentration of elements shows an increasing trend along the river channel downstream. The population density is generally high in lower section of the basin, indicating population density as the major factor for elemental concentration.
3.3. Contribution of Chemical Load from Each Tributary to Main Stream. Samples from six tributaries before the confluence to the main stream were observed in order to identify the contribution of chemical load to the main stream. As the tributaries Dhobhi Khola and Bishnumati flow through highly urbanized and densely populated areas of Kathmandu Valley, the elemental concentrations were high. The average concentration of elements such as $\mathrm{Mn}, \mathrm{Cr}, \mathrm{Ni}, \mathrm{Cu}, \mathrm{Zn}, \mathrm{Rb}$, $\mathrm{Mo}$, and $\mathrm{Cd}$ was highest in the Dhobhi Khola followed by Bishnumati. Similarly, for major ions, $\mathrm{Cl}^{-}, \mathrm{SO}_{4}{ }^{2-}, \mathrm{Na}^{+}$, and $\mathrm{NH}_{4}{ }^{-}$were highest in the Dhobhi Khola whereas $\mathrm{F}^{-}$and $\mathrm{NO}_{3}{ }^{-}$were highest in the Bishnumati. The elemental and ionic concentrations were relatively lower in the Bagmati and Manohora. Therefore, the elemental and the major ions concentrations were found to be high in the section with high population density, suggesting the major sources were from anthropogenic inputs into the river system.

3.4. Enrichment Factor and Source Identification. The EF of Bagmati River has been shown in Figure 4. The elements showed substantially different EF; lowest value was detected for $\mathrm{Ga}(0.133,0.199$, and 0.22$)$ and highest for Cd (3755.29, 38007.99, and 59322.45) in headwaters and suburban and urban sections of the river, respectively. The elements can be divided into three groups: the first group includes nonenriched elements $(\mathrm{EF}<4)$ such as Be, V, Mn, $\mathrm{Cr}, \mathrm{Co}, \mathrm{Zn}, \mathrm{Ga}, \mathrm{Rb}$, and $\mathrm{Y}$ in headwater, Be V, Co, Ga, $\mathrm{Rb}$, and $\mathrm{Y}$ in semiurban areas, and $\mathrm{Be}, \mathrm{V}, \mathrm{Co}$, and $\mathrm{Y}$ in urban areas indicating crustal origin. The second group has intermediately enriched elements (EF between 4 and 10) such as $\mathrm{Zn}$ in headwater, $\mathrm{Mn}, \mathrm{Cr}, \mathrm{Cu}$, and $\mathrm{Zn}$ in semiurban areas, and $\mathrm{Mn}, \mathrm{Cr}$, and $\mathrm{Rb}$ in urban areas. The third group has highly enriched elements $(\mathrm{EF}>10)$ such as Sc and Cd in 


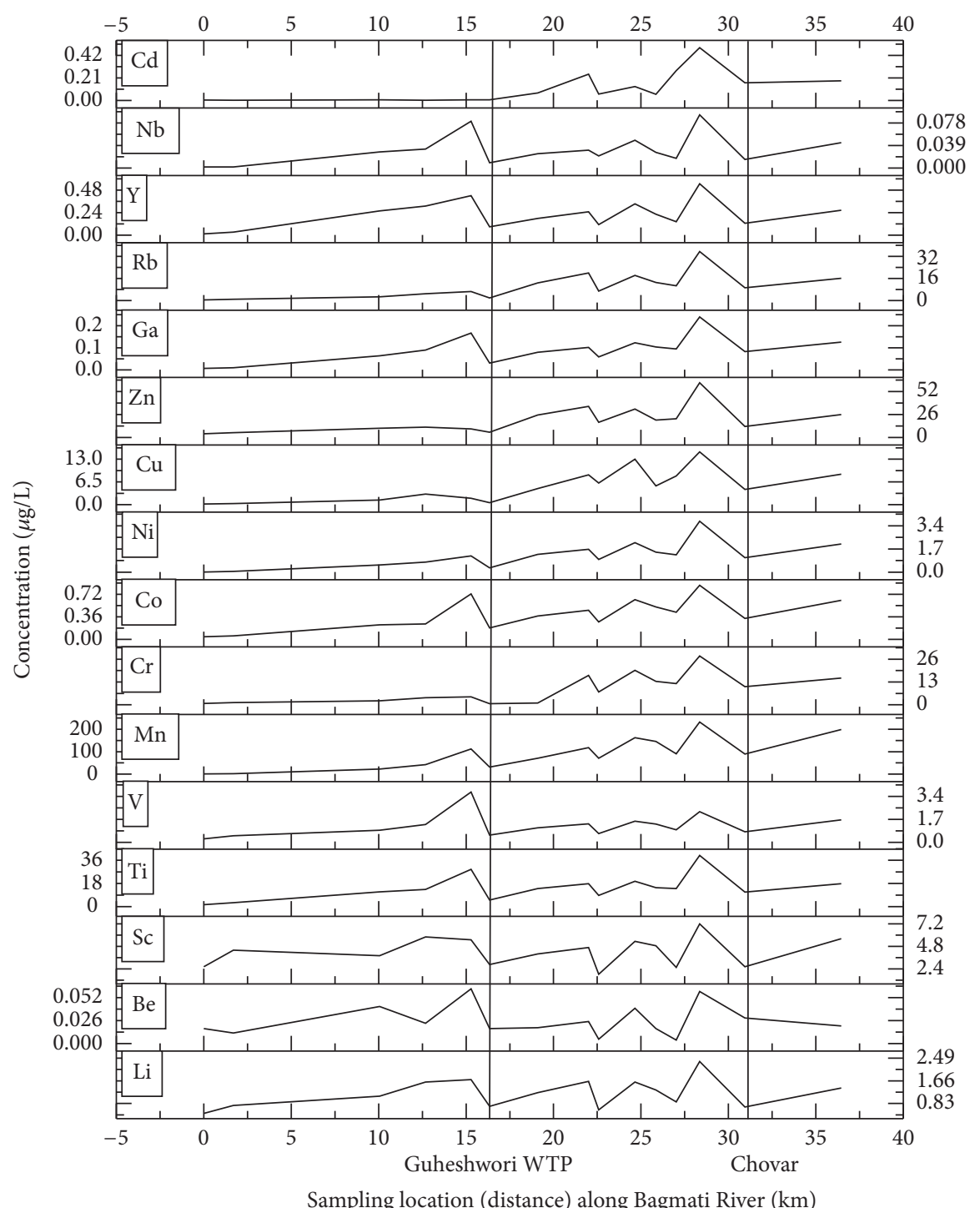

Figure 3: Changes in chemical composition of the Bagmati River from Sundarijal (headwater) to the area downstream (urban area) about $37 \mathrm{~km}$ at Khokana, within the Kathmandu Valley, where the concentration of elements is expressed in $\mu \mathrm{g} / \mathrm{L}$.

headwater and semiurban areas and $\mathrm{Sc}, \mathrm{Cu}, \mathrm{Zn}$, and $\mathrm{Cd}$ in urban areas indicating anthropogenic origin. The EF of $\mathrm{Cd}$ was extremely high in all the samples. Higher $\mathrm{Cd}$ value might have been attributed to industrial activity, fuel burning, and traffic [59-62] and also leachates from defused NI-Cd batteries and $\mathrm{Cd}$ plated items. The other highly enriched elements (e.g., Sc, Zn, and Co), were also highly enriched in urban section compared to the headwaters. Such a result may be because of high human population in urban areas where the major role is played by sewage effluent, untreated domestic waste, industrial activities, mining, traffic pollution, and landfill sites at the river banks [63, 64]. Similarly, Mn was intermediately enriched in semiurban and urban section of the Bagmati river basin in Kathmandu Valley. The sources of $\mathrm{Mn}$ could be from combustion of unleaded gasoline and industrial activities [65].

Furthermore, PCA analysis was applied for the results of trace elements from the Bagmati River water to understand the elemental associations and their origins based on factor loadings $[36,66,67]$. Three principal components (PCs) were extracted from 17 elements. The $\mathrm{PCl}$ has high loadings of $\mathrm{Nb}, \mathrm{Y}, \mathrm{V}, \mathrm{Be}, \mathrm{Ga}$, and Ti; PC2 has Mn, Co, Ni, Cr, and Mo; and PC3 has $\mathrm{Cd}, \mathrm{Cu}$, and $\mathrm{Zn}$ (Table 4). The total principal component together explained $91 \%$ of variance (PC1, 69.3\%; PC2, 12.83\%; and PC3, 8.8\%). The elements in the first component are from the weathering of catchment rocks and soils mainly due to construction of roads and buildings beside the river. Construction of roads beside the river has become very popular in the city. The source of $\mathrm{V}$ may be from tar which is used for the construction of roads. All elements in PC2 ( $\mathrm{Mn}, \mathrm{Co}, \mathrm{Ni}, \mathrm{Cr}$, and $\mathrm{Mo}$ ) are potentially harmful metals. High concentration of these metals is believed to be associated with anthropogenic origin partially due to discharge of untreated sewage into the river water while some are from the garment, carpet, and other factories. These elements could also have originated from burning of 


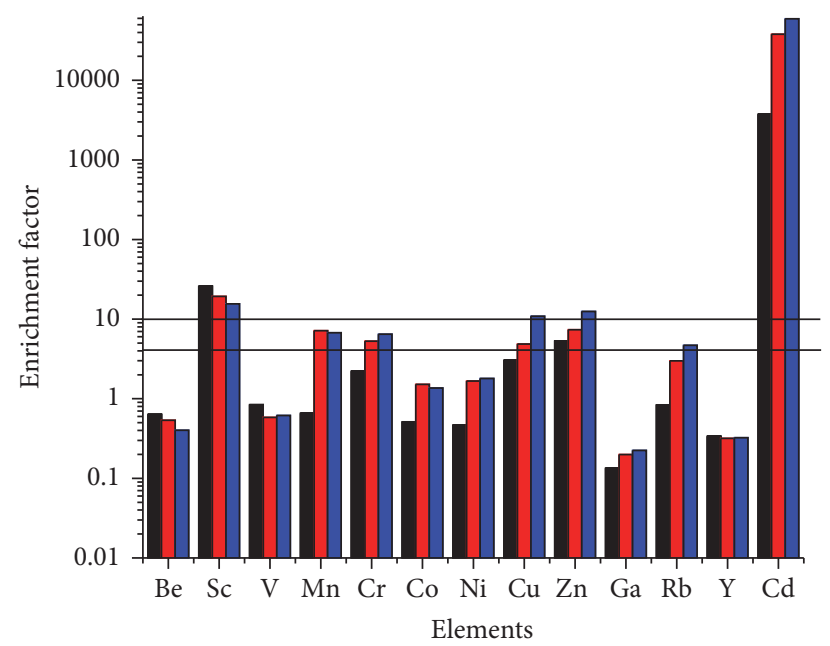

$\square$ Headwater
$\square$ Suburban
$\square$ Urban

FIGURE 4: Average enrichment factor of trace elements in the water of Bagmati River basin presented as three sections: headwaters and suburban and urban areas within the Kathmandu Valley.

TABle 4: Principal Component Analysis (PCA) of elements in the Bagmati River basin within Kathmandu Valley.

\begin{tabular}{lccc}
\hline Elements & \multicolumn{3}{c}{ Component } \\
\hline $\mathrm{Nb}$ & $\mathbf{. 8 8 0}$ & .389 & 3 \\
$\mathrm{Y}$ & $\mathbf{. 8 8 0}$ & .309 & .050 \\
$\mathrm{~V}$ & .868 & .115 & .211 \\
$\mathrm{Be}$ & .865 & .010 & .209 \\
$\mathrm{Ga}$ & .743 & .573 & .276 \\
$\mathrm{Ti}$ & .716 & .501 & .303 \\
$\mathrm{Mn}$ & .297 & .850 & .429 \\
$\mathrm{Co}$ & .532 & .783 & .250 \\
$\mathrm{Ni}$ & .309 & .770 & .198 \\
$\mathrm{Cr}$ & .222 & .763 & .540 \\
$\mathrm{Mo}$ & .047 & .723 & .566 \\
$\mathrm{Cd}$ & .132 & .208 & .485 \\
$\mathrm{Cu}$ & .251 & .459 & .817 \\
$\mathrm{Zn}$ & .342 & .494 & .771 \\
$\mathrm{Rb}$ & .221 & .629 & .738 \\
$\mathrm{Li}$ & .523 & .350 & .725 \\
$\mathrm{Sc}$ & .550 & .181 & .674 \\
\hline$\%$ of variance & $69.31 \%$ & $12.83 \%$ & .638 \\
\hline Eigen value & 11.79 & 2.18 & $8.79 \%$ \\
\hline
\end{tabular}

fossil fuels and solid waste dumping [32, 59, 60, 68, 69]. The elements in PC3 $(\mathrm{Cd}, \mathrm{Cu}$, and $\mathrm{Zn})$ can be attributed to anthropogenic origin. The sources of $\mathrm{Cd}$ are generally from coal combustion for heating purpose and also from vehicular emission. Other possible sources of $\mathrm{Zn}, \mathrm{Cd}$, and Co may be electronic waste and batteries that are disposed into the river system. A very good correlation between $\mathrm{Zn}$ and $\mathrm{Cu}\left(r^{2}=\right.$
0.96) as well as $\mathrm{Cu}$ and $\mathrm{Cd}\left(r^{2}=0.85\right)$ further indicates their similarity of sources.

3.5. Water Quality and Ecological Risk Assessment. The water of Bagmati River is considered holy where many people bathe, drink, or wash their body, besides using the area for cremation, especially near some temples on the banks of the river. The HQs of trace metals for local residents and devotees visiting the Pashupatinath, Guhyeshwori, and many other temples located on the banks of the Bagmati River within the Kathmandu Valley are summarized in Table 5. Eleven metals were considered for HQ analysis because of their available Rfd ingestion and dermal values. HQs $>1$ suggest that the water could possibly have deleterious effect on the residents' health [70]. Therefore, $\mathrm{HQ}_{\text {ingestion }}$ of heavy metal in the study area was studied and found in the order of $\mathrm{Sb}>\mathrm{Mn}>\mathrm{Cr}>\mathrm{V}>\mathrm{Co}>\mathrm{Cd}>\mathrm{Cu}>\mathrm{Zn}>\mathrm{Ni}>$ $\mathrm{Li}>\mathrm{Mo}$. In this study, the $\mathrm{HQ}_{\text {ingestion }}$ and $\mathrm{HQ}_{\text {dermal }}$ values were found to be less than unity, which indicates that the water may have little or no health effect; however for some samples of $\mathrm{Sb}$ and $\mathrm{Mg}$, the values were close to unity. Among all the elements studied, the highest $\mathrm{HQ}_{\text {ingestion }}$ was found for Sb followed by Mn, which was similar to that of Yellow river delta [46] and drinking water in Karachi [70] but was however higher than the study conducted in a playground of Madrid [71], some rivers of China [72, 73], and streams in northern Pakistan [45]. $\mathrm{HQ}_{\text {ingestion }}$ for $\mathrm{Cr}$ was also higher compared to other studies form China, Pakistan, and other parts of the world. Similarly $\mathrm{HQ}_{\text {ingestion }}$ for Cd was higher than the studies conducted in the Yangtze River in Nanjing [44], Madrid [71], Dan River [72], and Upper Han [73] but was however lower than Yellow river delta [46] and Besham area in northern Pakistan but comparable to Jilal-dubair and Alpuri of Pakistan [45]. Even though the overall $\mathrm{HQ}_{\text {ingestion }}$ and $\mathrm{HQ}_{\text {dermal }}$ values are less than 1 , special attention should be paid to elements like $\mathrm{Sb}, \mathrm{Mn}$, and $\mathrm{Cr}$, and strict measures should be taken to maintain a healthy aquatic ecosystem for this holy river in the heart of Kathmandu.

\section{Conclusion}

This study provides the detailed information on water quality of the Bagmati River and its tributaries within the Kathmandu Valley. Since the origin of all the tributaries of Bagmati River is within the Kathmandu Valley, the river water quality is mostly determined by human activities within the valley. Most of the elements and ions showed higher concentration in the urban section of the river compared to the headwaters and exhibited a dependency with the population density adjacent to the river. Meanwhile, natural governing factor like weathering of soil parent materials seems to play insignificant role. The concentration of nitrate and sulfate in most of the samples in the lower reaches of the river was found to be very low due to depletion of dissolved oxygen. The concentration of $\mathrm{Mn}, \mathrm{Cd}, \mathrm{Cr}, \mathrm{Co}$, and $\mathrm{Zn}$ was particularly higher in urban and semiurban section of the river. $\mathrm{Cd}, \mathrm{Co}$, and $\mathrm{Zn}$ were also highly enriched indicating anthropogenic origin. The source of $\mathrm{V}$ and many other elements can be attributed to the construction of roads beside the river mainly due to 
TABLE 5: Reference dose and hazard quotient for each element.

\begin{tabular}{|c|c|c|c|c|c|}
\hline Elements & $\mathrm{RfD}_{\text {ingestion }}$ & $\mathrm{RfD}_{\text {dermal }}$ & & $\mathrm{HQ}_{\text {ingestion }}$ & $\mathrm{HQ}_{\text {dermal }}$ \\
\hline \multirow{3}{*}{$\mathrm{Li}$} & \multirow{3}{*}{20} & \multirow{3}{*}{10} & Max & $4.11 E-03$ & $6.90 E-06$ \\
\hline & & & Min & $3.84 E-04$ & $6.44 E-07$ \\
\hline & & & Mean & $1.87 E-03$ & $3.13 E-06$ \\
\hline \multirow{3}{*}{ V } & \multirow{3}{*}{1} & \multirow{3}{*}{0.01} & Max & $1.02 E-01$ & $8.61 E-03$ \\
\hline & & & Min & $7.07 E-03$ & $5.94 E-04$ \\
\hline & & & Mean & $3.92 E-02$ & $3.29 E-03$ \\
\hline \multirow{3}{*}{$\mathrm{Mn}$} & \multirow{3}{*}{20} & \multirow{3}{*}{0.8} & $\operatorname{Max}$ & $3.52 E-01$ & $7.39 E-03$ \\
\hline & & & Min & $7.16 E-04$ & $1.50 E-05$ \\
\hline & & & Mean & $1.45 E-01$ & $3.04 E-03$ \\
\hline \multirow{3}{*}{$\mathrm{Cr}$} & \multirow{3}{*}{3} & \multirow{3}{*}{0.015} & $\operatorname{Max}$ & $2.72 E-01$ & $9.14 E-02$ \\
\hline & & & Min & $5.75 E-03$ & $1.93 E-03$ \\
\hline & & & Mean & $1.04 E-01$ & $8.89 E-03$ \\
\hline \multirow{3}{*}{ Co } & \multirow{3}{*}{0.3} & \multirow{3}{*}{0.0003} & Max & $7.89 E-02$ & $2.65 E-02$ \\
\hline & & & Min & $3.93 E-03$ & $1.32 E-03$ \\
\hline & & & Mean & $3.89 E-02$ & $3.51 E-02$ \\
\hline \multirow{3}{*}{$\mathrm{Ni}$} & \multirow{3}{*}{20} & \multirow{3}{*}{5.4} & Max & $5.66 E-03$ & $3.52 E-06$ \\
\hline & & & Min & $3.29 E-05$ & $2.05 E-08$ \\
\hline & & & Mean & $2.00 E-03$ & $1.24 E-06$ \\
\hline \multirow{3}{*}{$\mathrm{Cu}$} & \multirow{3}{*}{40} & \multirow{3}{*}{12} & $\operatorname{Max}$ & $2.51 E-02$ & $7.02 E-05$ \\
\hline & & & Min & $1.22 E-04$ & $3.41 E-07$ \\
\hline & & & Mean & $4.70 E-03$ & $1.32 E-05$ \\
\hline \multirow{3}{*}{$\mathrm{Zn}$} & \multirow{3}{*}{300} & \multirow{3}{*}{60} & $\operatorname{Max}$ & $8.83 E-03$ & $2.23 E-05$ \\
\hline & & & Min & $3.78 E-04$ & $9.53 E-07$ \\
\hline & & & Mean & $2.10 E-03$ & $5.30 E-06$ \\
\hline \multirow{3}{*}{ Mo } & \multirow{3}{*}{5} & \multirow{3}{*}{1.9} & Max & $6.41 E-03$ & $1.42 E-05$ \\
\hline & & & Min & $2.03 E-04$ & $4.48 E-07$ \\
\hline & & & Mean & $1.82 E-03$ & $4.02 E-06$ \\
\hline \multirow{3}{*}{$\mathrm{Cd}$} & \multirow{3}{*}{0.5} & & Max & $1.33 E-01$ & $1.11 E-02$ \\
\hline & & 0.005 & Min & $1.10 E-04$ & $9.21 E-06$ \\
\hline & & & Mean & $1.29 E-02$ & $1.08 E-03$ \\
\hline & & & $\operatorname{Max}$ & $8.29 E-01$ & $3.48 E-02$ \\
\hline $\mathrm{Sb}$ & 0.4 & 0.008 & Min & $4.47 E-02$ & $1.88 E-03$ \\
\hline & & & Mean & $2.24 E-01$ & $9.42 E-03$ \\
\hline
\end{tabular}

the use of tar, cement, and other raw materials. Primary health risk assessment for trace metals indicated that the surface water in Bagmati River has low risk; however, some metals like $\mathrm{Sb}$ and $\mathrm{Mg}$ were close to unity indicating possible threat. Furthermore, this study could be used as reference for further research as this paper provides the first health risk assessment of trace metals for urban river in Nepal. At a glance, the water quality of Bagmati River is governed by anthropogenic sources such as sewage effluents, industrial waste, and dumping of solid waste besides the river. Overall, the Bagmati River is polluted and is comparable with some of the most polluted rivers around the world and needs restoration.

\section{Competing Interests}

The authors declare no conflict of interests regarding the publication of this paper.

\section{Acknowledgments}

This study was supported by the Strategic Priority Research Program (B) of the Chinese Academy of Sciences (XDB03030504), the National Natural Science Foundation of China (41225002), and the Academy of Finland (Decision no. 268170). The authors would like to thank Muhammad Adnan for helping them in Figure 1.

\section{References}

[1] P. D. Armitage, M. J. Bowes, and H. M. Vincent, "Long-term changes in macroinvertebrate communities of a heavy metal polluted stream: the river Nent (Cumbria, UK) after 28 years," River Research and Applications, vol. 23, no. 9, pp. 997-1015, 2007.

[2] G.-L. Yuan, C. Liu, L. Chen, and Z. Yang, "Inputting history of heavy metals into the inland lake recorded in sediment profiles: 
Poyang Lake in China," Journal of Hazardous Materials, vol. 185, no. 1, pp. 336-345, 2011.

[3] M. S. Islam, M. K. Ahmed, M. Raknuzzaman, M. Habibullah Al- Mamun, and M. K. Islam, "Heavy metal pollution in surface water and sediment: a preliminary assessment of an urban river in a developing country," Ecological Indicators, vol. 48, pp. 282291, 2015.

[4] M. Sillanpää, R. Hulkkonen, and A. Manderscheid, "Drinking water quality in the alpine pastures of the eastern Tibetan plateau," Rangifer, vol. 24, no. 15, pp. 47-52, 2004.

[5] T. Srebotnjak, G. Carr, A. de Sherbinin, and C. Rickwood, "A global Water Quality Index and hot-deck imputation of missing data," Ecological Indicators, vol. 17, pp. 108-119, 2012.

[6] S. Su, R. Xiao, X. Mi, X. Xu, Z. Zhang, and J. Wu, "Spatial determinants of hazardous chemicals in surface water of Qiantang River, China," Ecological Indicators, vol. 24, pp. 375-381, 2013.

[7] M. S. Islam, S. Han, M. K. Ahmed, and S. Masunaga, "Assessment of trace metal contamination in water and sediment of some rivers in Bangladesh," Journal of Water and Environment Technology, vol. 12, no. 2, pp. 109-121, 2014.

[8] B. Koukal, J. Dominik, D. Vignati et al., "Assessment of water quality and toxicity of polluted Rivers Fez and Sebou in the region of Fez (Morocco)," Environmental Pollution, vol. 131, no. 1, pp. 163-172, 2004.

[9] K. M. Mohiuddin, H. M. Zakir, K. Otomo, S. Sharmin, and N. Shikazono, "Geochemical distribution of trace metal pollutants in water and sediments of downstream of an urban river," International Journal of Environmental Science \& Technology, vol. 7, no. 1, pp. 17-28, 2010.

[10] R. J. Gibbs, "The geochemistry of the Amazon River system: part I. The factors that control the salinity and the composition and concentration of the suspended solids," Geological Society of America Bulletin, vol. 78, no. 10, pp. 1203-1232, 1967.

[11] J. Gaillardet, B. Dupré, P. Louvat, and C. J. Allègre, "Global silicate weathering and $\mathrm{CO}_{2}$ consumption rates deduced from the chemistry of large rivers," Chemical Geology, vol. 159, no. 1-4, pp. 3-30, 1999.

[12] J. Zhang, Z. F. Zhang, S. M. Liu, Y. Wu, H. Xiong, and H. T. Chen, "Human impacts on the large world rivers: would the Changjiang (Yangtze River) be an illustration?" Global Biogeochemical Cycles, vol. 13, no. 4, pp. 1099-1105, 1999.

[13] C. J. Vörösmarty, P. McIntyre, M. O. Gessner et al., "Global threats to human water security and river biodiversity," Nature, vol. 467, no. 7315, pp. 555-561, 2010.

[14] N. E. Peters, Evaluation of Environmental Factors Affecting Yields of Major Dissolved Ions of sTreams in the United States, USGPO, 1984.

[15] M. Meybeck, Man and River Interface: Multiple Impacts on Water and Particulates Chemistry Illustrated in the Seine River Basin, Oceans, Rivers and Lakes: Energy and Substance Transfers at Interfaces, Springer, Berlin, Germany, 1998.

[16] S. Roy, J. Gaillardet, and C. J. Allègre, "Geochemistry of dissolved and suspended loads of the Seine river, France: anthropogenic impact, carbonate and silicate weathering," Geochimica et Cosmochimica Acta, vol. 63, no. 9, pp. 1277-1292, 1999.

[17] C. Flintrop, B. Hohlmann, T. Jasper et al., "Anatomy of pollution: rivers of north Rhine-Westphalia, Germany," American Journal of Science, vol. 296, no. 1, pp. 58-98, 1996.

[18] ENPHO, Monitoring and Assessment of Water Quality in the Shivapuri Watershed, HMG/FAO, 1997.
[19] DHM, Water Quality Summary 1992-2006, Ministry of Science and Technology, Government of Nepal, 2008.

[20] M. P. Bhatt and W. H. McDowell, "Evolution of chemistry along the Bagmati drainage network in Kathmandu valley," Water, Air, and Soil Pollution, vol. 185, no. 1, pp. 165-176, 2007.

[21] P. R. Kannel, S. Lee, S. R. Kanel, S. P. Khan, and Y.-S. Lee, "Spatial-temporal variation and comparative assessment of water qualities of urban river system: a case study of the river Bagmati (Nepal)," Environmental Monitoring and Assessment, vol. 129, no. 1, pp. 433-459, 2007.

[22] M. P. Bhatt and K. H. Gardner, "Variation in DOC and trace metal concentration along the heavily urbanized basin in Kathmandu Valley, Nepal," Environmental Geology, vol. 58, no. 4, pp. 867-876, 2009.

[23] M. P. Bhatt, W. H. McDowell, K. H. Gardner, and J. Hartmann, "Chemistry of the heavily urbanized Bagmati River system in Kathmandu Valley, Nepal: export of organic matter, nutrients, major ions, silica, and metals," Environmental Earth Sciences, vol. 71, no. 2, pp. 911-922, 2014.

[24] H. G. Dill, B. D. Kharel, V. K. Singh, B. Piya, K. Busch, and M. Geyh, "Sedimentology and paleogeographic evolution of the intermontane Kathmandu basin, Nepal during the Pliocene and Quaternary," Journal of Asian Earth Sciences, vol. 20, pp. 255266, 2001.

[25] R. Fujii and H. Sakai, "Paleoclimatic changes during the last 2.5 myr recorded in the Kathmandu Basin, Central Nepal Himalayas," Journal of Asian Earth Sciences, vol. 20, no. 3, pp. 255-266, 2002.

[26] B. Pradhan, Water quality assessment of the Bagmati River and its tributaries, Kathmandu Valley, Nepal, 1998.

[27] O. M. Shrestha, A. Koirala, J. Hanisch, K. Busch, M. Kerntke, and S. Jäger, "A geo-environmental map for the sustainable development of the Kathmandu Valley, Nepal," GeoJournal, vol. 49, no. 2, pp. $165-172,1999$.

[28] K. Kc, Optimizing Water use in Kathmandu valley (ADB TA3700), Final Draft Report on Groundwater/Hydrogeology in Kathmandu Valley, 2003.

[29] O. Shrestha, A. Koirala, S. Karmacharya et al., Engineering and Environmental Geology Map of the Kathmandu Valley, Department of Mines and Geology, HMG, Kathmandu, Nepal, 1998.

[30] I. Jüttner, S. Sharma, B. M. Dahal, S. J. Ormerod, P. J. Chimonides, and E. J. Cox, "Diatoms as indicators of stream quality in the Kathmandu Valley and Middle Hills of Nepal and India," Freshwater Biology, vol. 48, no. 11, pp. 2065-2084, 2003.

[31] B. Rimal, "Application of remote sensing and gis, land use/land cover change in Kathmandu Metropolitan City, Nepal," Journal of Theoretical \& Applied Information Technology, vol. 23, no. 2, pp. 80-86, 2011.

[32] R. Paudyal, S. Kang, C. M. Sharma et al., "Major ions and trace elements of two selected rivers near Everest region, southern Himalayas, Nepal," Environmental Earth Sciences, vol. 75, no. 1, article 46, pp. 1-11, 2016.

[33] L. Tripathee, S. Kang, J. Huang et al., "Ionic composition of wet precipitation over the southern slope of central Himalayas, Nepal," Environmental Science and Pollution Research, vol. 21, no. 4, pp. 2677-2687, 2014.

[34] L. Tripathee, S. Kang, C. M. Sharma et al., "Preliminary health risk assessment of potentially toxic metals in surface water of the Himalayan Rivers, Nepal," Bulletin of Environmental Contamination and Toxicology, 2016. 
[35] L. Tripathee, S. Kang, J. Huang et al., "Concentrations of trace elements in wet deposition over the central Himalayas, Nepal," Atmospheric Environment, vol. 95, pp. 231-238, 2014.

[36] A. Franco-Uría, C. López-Mateo, E. Roca, and M. L. FernándezMarcos, "Source identification of heavy metals in pastureland by multivariate analysis in NW Spain," Journal of Hazardous Materials, vol. 165, no. 1-3, pp. 1008-1015, 2009.

[37] K. Kyllönen, V. Karlsson, and T. Ruoho-Airola, "Trace element deposition and trends during a ten year period in Finland," Science of the Total Environment, vol. 407, no. 7, pp. 2260-2269, 2009.

[38] Z. Cong, S. Kang, Y. Zhang, and X. Li, "Atmospheric wet deposition of trace elements to central Tibetan Plateau," Applied Geochemistry, vol. 25, no. 9, pp. 1415-1421, 2010.

[39] C. M. Sharma, S. Kang, M. Sillanpää et al., "Mercury and selected trace elements from a remote (gosainkunda) and an urban (Phewa) Lake Waters of Nepal," Water, Air, and Soil Pollution, vol. 226, article no. 6, 2015.

[40] C. Li, S. Kang, and Q. Zhang, "Elemental composition of Tibetan Plateau top soils and its effect on evaluating atmospheric pollution transport," Environmental Pollution, vol. 157, no. 8-9, pp. 2261-2265, 2009.

[41] S. R. Taylor and S. M. McLennan, "The geochemical evolution of the continental crust," Reviews of Geophysics, vol. 33, no. 2, pp. 241-265, 1995.

[42] L. Tripathee, S. Kang, D. Rupakheti et al., "Spatial distribution, sources and risk assessment of potentially toxic trace elements and rare earth elements in soils of the Langtang Himalaya, Nepal," Environmental Earth Sciences, vol. 75, article 1332, 2016.

[43] G. F. Birch and M. A. Olmos, "Sediment-bound heavy metals as indicators of human influence and biological risk in coastal water bodies," ICES Journal of Marine Science, vol. 65, no. 8, pp. 1407-1413, 2008.

[44] B. Wu, D. Y. Zhao, H. Y. Jia, Y. Zhang, X. X. Zhang, and S. P. Cheng, "Preliminary risk assessment of trace metal pollution in surface water from Yangtze River in Nanjing section, China," Bulletin of Environmental Contamination and Toxicology, vol. 82, no. 4, pp. 405-409, 2009.

[45] S. Muhammad, M. T. Shah, and S. Khan, "Health risk assessment of heavy metals and their source apportionment in drinking water of Kohistan region, northern Pakistan," Microchemical Journal, vol. 98, no. 2, pp. 334-343, 2011.

[46] S. Song, F. Li, J. Li, and Q. Liu, "Distribution and contamination risk assessment of dissolved trace metals in surface waters in the yellow river delta," Human and Ecological Risk Assessment, vol. 19, no. 6, pp. 1514-1529, 2013.

[47] USEPA, Risk Assessment Guidance for Superfund Volume I: Human Health Evaluation Manual (Part E, Supplemental Guidance for Dermal Risk Assessment), EPA/540/R/99/005 OSWER 9285.7-02EP PB99-963312, Office of Superfund Remediation and Technology Innovation USA, July 2004.

[48] US EPA, “Guidelines for carcinogen risk assessment," Tech. Rep. EPA/630/P-03/001F, Risk Assessment Forum, Washington, DC, USA, 2005.

[49] S. C. McCutcheon, J. L. Martin, T. O. Barnwell Jr., and D. Maidment, "Water quality," in Handbook of Hydrology, pp. 11.1111.73, McGraw-Hill, New York, NY, USA, 1992.

[50] M. Meybeck and R. Helmer, "The quality of rivers: from pristine stage to global pollution," Global and Planetary Change, vol. 1, no. 4, pp. 283-309, 1989.
[51] A. T. Herlihy, J. L. Stoddard, and C. B. Johnson, "The relationship between stream chemistry and watershed land cover data in the mid-Atlantic Region, US,' Water, Air, and Soil Pollution, vol. 105, no. 1, pp. 377-386, 1998.

[52] F. Wendland, H. Albert, M. Bach, and R. Schmidt, "Potential nitrate pollution of groundwater in Germany: a supraregional differentiated model," Environmental Geology, vol. 24, no. 1, pp. $1-6,1994$.

[53] U. von Gunten and J. Zobrist, "Biogeochemical changes in groundwater-infiltration systems: column studies," Geochimica et Cosmochimica Acta, vol. 57, no. 16, pp. 3895-3906, 1993.

[54] R. Collins and A. Jenkins, "The impact of agricultural land use on stream chemistry in the Middle Hills of the Himalayas, Nepal," Journal of Hydrology, vol. 185, no. 1-4, pp. 71-86, 1996.

[55] L. Sörme and R. Lagerkvist, "Sources of heavy metals in urban wastewater in Stockholm," Science of the Total Environment, vol. 298, no. 1-3, pp. 131-145, 2002.

[56] P. Le Pape, S. Ayrault, and C. Quantin, “Trace element behavior and partition versus urbanization gradient in an urban river (Orge River, France)," Journal of Hydrology, vol. 472-473, pp. 99-110, 2012.

[57] WHO, Guidelines for DrinkingWater Quality. Recommendations, World Health Organization, Geneva, Switzerland, 2011.

[58] X. Huang, M. Sillanpää, E. T. Gjessing, S. Peräniemi, and R. D. Vogt, "Environmental impact of mining activities on the surface water quality in Tibet: gyama valley," Science of the Total Environment, vol. 408, no. 19, pp. 4177-4184, 2010.

[59] D. Barałkiewicz and J. Siepak, "Chromium, nickel and cobalt in environmental samples and existing legal norms," Polish Journal of Environmental Studies, vol. 8, no. 4, pp. 201-208, 1999.

[60] J. P. Wise Sr., R. Payne, S. S. Wise et al., "A global assessment of chromium pollution using sperm whales (Physeter macrocephalus) as an indicator species," Chemosphere, vol. 75, no. 11, pp. 1461-1467, 2009.

[61] H.-F. Sun, Y.-H. Li, Y.-F. Ji, L.-S. Yang, W.-Y. Wang, and H.-R. Li, "Environmental contamination and health hazard of lead and cadmium around Chatian mercury mining deposit in western Hunan Province, China," Transactions of Nonferrous Metals Society of China, vol. 20, no. 2, pp. 308-314, 2010.

[62] C. K. Adokoh, E. A. Obodai, D. K. Essumang, Y. Serfor-Armah, B. J. B. Nyarko, and A. Asabere-Ameyaw, "Statistical evaluation of environmental contamination, distribution and source assessment of heavy metals (Aluminum, Arsenic, Cadmium, and Mercury) in some lagoons and an estuary along the coastal belt of Ghana," Archives of Environmental Contamination and Toxicology, vol. 61, no. 3, pp. 389-400, 2011.

[63] K. Adachi and Y. Tainosho, "Characterization of heavy metal particles embedded in tire dust," Environment International, vol. 30, no. 8, pp. 1009-1017, 2004.

[64] J. O. Nriagu, "A history of global metal pollution," Science, vol. 272, no. 5259, pp. 223-224, 1996.

[65] J. Zayed, A. Guessous, J. Lambert, G. Carrier, and S. Philippe, "Estimation of annual Mn emissions from MMT source in the Canadian environment and the Mn pollution index in each province," Science of the Total Environment, vol. 312, no. 1-3, pp. 147-154, 2003.

[66] T. Kikuchi, T. Furuichi, H. T. Hai, and S. Tanaka, "Assessment of heavy metal pollution in river water of Hanoi, Vietnam using multivariate analyses," Bulletin of Environmental Contamination and Toxicology, vol. 83, no. 4, pp. 575-582, 2009. 
[67] A. Z. Garizi, V. Sheikh, and A. Sadoddin, "Assessment of seasonal variations of chemical characteristics in surface water using multivariate statistical methods," International Journal of Environmental Science \& Technology, vol. 8, no. 3, pp. 581-592, 2011.

[68] J. M. Pacyna, A. Semb, and J. E. Hanssen, "Emission and longrange transport of trace elements in Europe," Tellus, vol. 36B, no. 3, pp. 163-178, 1984.

[69] Y. Teng, S. Ni, C. Zhang, J. Wang, X. Lin, and Y. Huang, "Environmental geochemistry and ecological risk of vanadium pollution in Panzhihua mining and smelting area, Sichuan, China," Chinese Journal of Geochemistry, vol. 25, no. 4, pp. 379385, 2006.

[70] Z. Karim, "Risk assessment of dissolved trace metals in drinking water of Karachi, Pakistan," Bulletin of Environmental Contamination and Toxicology, vol. 86, no. 6, pp. 676-678, 2011.

[71] E. De Miguel, I. Iribarren, E. Chacón, A. Ordoñez, and S. Charlesworth, "Risk-based evaluation of the exposure of children to trace elements in playgrounds in Madrid (Spain)," Chemosphere, vol. 66, no. 3, pp. 505-513, 2007.

[72] Q. Meng, J. Zhang, Z. Zhang, and T. Wu, "Geochemistry of dissolved trace elements and heavy metals in the Dan River Drainage (China): distribution, sources, and water quality assessment," Environmental Science and Pollution Research, pp. 8091-8103, 2016.

[73] S. Li and Q. Zhang, "Risk assessment and seasonal variations of dissolved trace elements and heavy metals in the Upper Han River, China," Journal of Hazardous Materials, vol. 181, no. 1-3, pp. 1051-1058, 2010. 

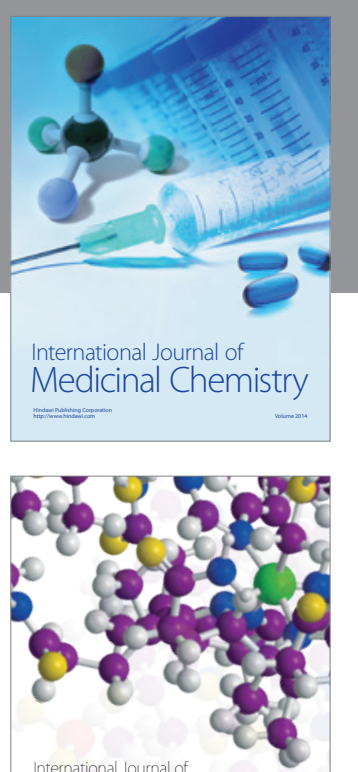

Carbohydrate Chemistry

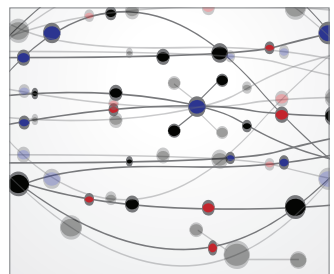

The Scientific World Journal
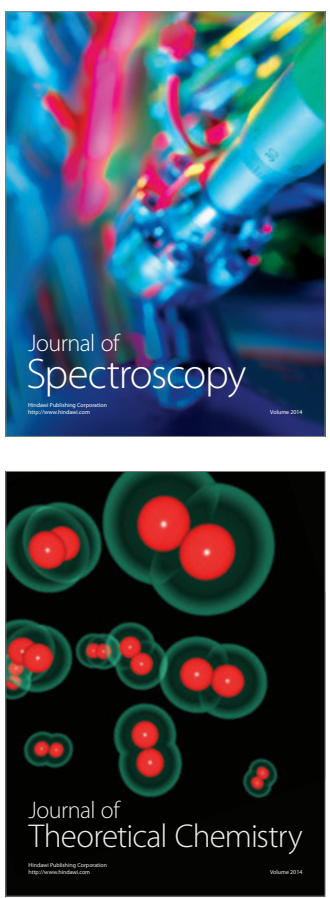
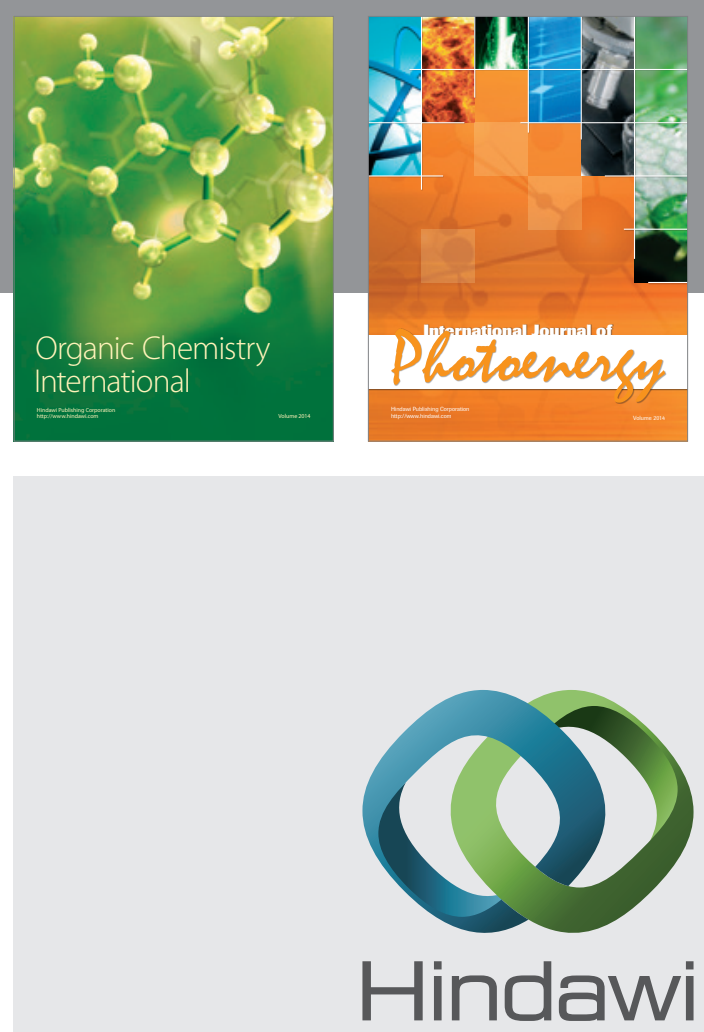

Submit your manuscripts at

http://www.hindawi.com

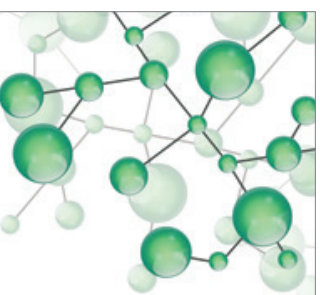

International Journal of

Inorganic Chemistry

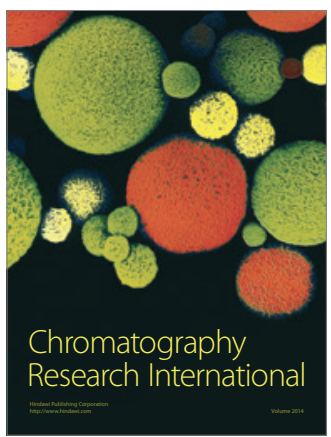

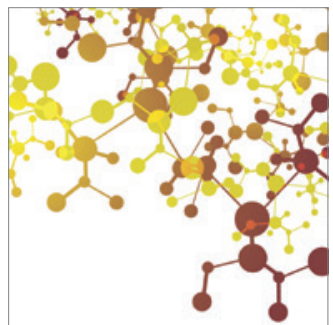

Applied Chemistry
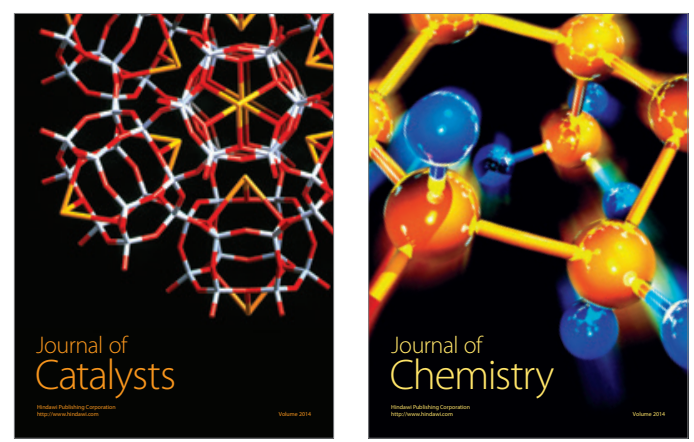
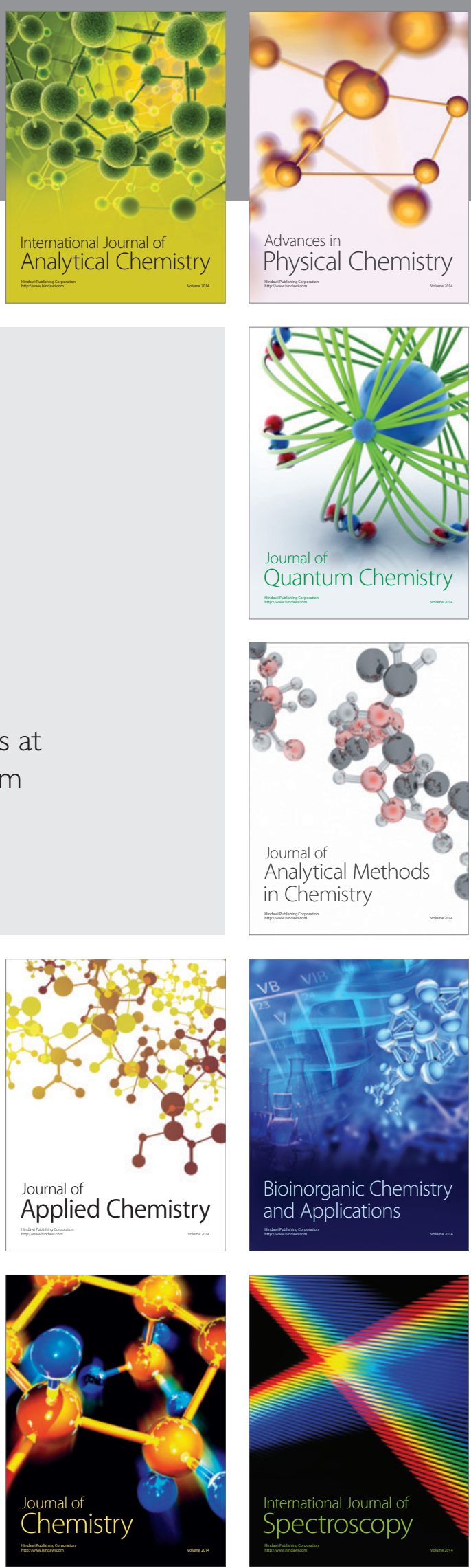